\title{
Influence of Teachers Preparedness on Performance of Pupils in Mathematics in Lower Primary Schools in Aberdares Region of Kenya
}

\author{
Loise Wangechi Kariuki ${ }^{1 *}$, Johannes Njagi Njoka ${ }^{1}$, Zachariah Kariuki Mbugua ${ }^{1}$ \\ 1 Department of Psychology \& Communication Technology, Karatina University, 195710101 Karatina, KENYA
}

*Corresponding Author: lwangecy@gmail.com

Citation: Kariuki, L. W., Njoka, J. N. and Mbugua, Z. K. (2019). Influence of Teachers Preparedness on Performance of Pupils in Mathematics in Lower Primary Schools in Aberdares Region of Kenya. European Journal of STEM Education, 4(1), 01. https://doi.org/10.20897/ejsteme/3931

Published: April 29, 2019

\begin{abstract}
Performance in Mathematics among pupils in lower primary schools in Kenya is a problem that continues to be a concern to parents, teachers and stakeholders in education. Teacher related factors and in particular teacher preparedness has been cited as a major contributing factor to poor teaching methods which fundamentally translates to pupils' poor performance. The purpose of the study was to evaluate the influence of teacher preparedness on pupils' performance in Mathematics in lower primary schools in the Aberdares region of Kenya. The objectives of the study were to; evaluate the influence of teachers' preparation of lesson plans on pupils' performance in Mathematics in lower primary schools and assess the influence of teachers' preparation of schemes of work on pupils' performance in Mathematics in lower primary schools from the Aberdares region in Kenya. The following hypothesis were tested; Ho1: There is no statistically significant relationship between teachers' preparation of lesson plans and performance in Mathematics among pupils in lower primary schools, Ho2: There is no statistically significant relationship between teachers' preparation of schemes of work and pupils' performance in Mathematics in lower primary schools. The study adopted the descriptive survey research design. The study was guided by the Social Constructivism Theory (SCT) advanced by Vygotsky (1978). The target population for the study consisted of all the 385 teachers and 1320 pupils in the public primary schools in Aberdares region of Kenya. A sample of schools was selected using Gay's 10-20\% sampling principle which yielded a sample size of 77 teachers and 264 pupils. Data for the study was collected using questionnaires administered to the respondents. The t-test statistic was computed to test the hypothesis which stated that there was no statistically significant relationship between teachers' preparation of lessons and pupils' performance in Mathematics. The t-test yielded a p-value $=0.027$ which was less than the $\alpha$-value of 0.05 hence the hypothesis was rejected. It was concluded that there were differences in pupils' performance in Mathematics depending on teacher preparation of lesson. Regarding the preparation of schemes of work, the computed t- test statistic yielded a p-value $=.039$ which was less than the p-value of .05 . Therefore the null hypothesis was accepted. It was concluded that the pupils Mathematics mean scores were relatively the same regardless of whether the teacher prepared schemes of work or not. It is recommended that there is need for teachers to institutionalize as a best practice the preparation of professional documents before commencement of teaching.
\end{abstract}

Keywords: teacher preparedness, pedagogy, professional documents, lesson plans, schemes of work 


\section{INTRODUCTION}

Stakeholders continue to be concerned with the performance of pupils in Mathematics especially in lower primary section of education in Kenya. Performance in Mathematics among pupils in lower primary schools in Kenya has been reported to be extremely wanting. Uwezo Kenya (2016) in their report entitled, "Are our children learning?" indicated only 3 out of 10 children in Class 3 could do Class 2 work. On average, 1 out of 10 children in Kenyan primary schools were completing Class 8 without having acquired the basic competencies expected of a child completing Class 2. The persistent poor performance of pupils in Mathematics requires for investigation into the underlying variables and in particular into curriculum delivery methodologies. In the $2018 \mathrm{KCPE}$ results, the mean score in the region was 35\%. Oketch, Mutisya, Ngware and Sagwe (2010) assert that the competence of learners' in numeracy and literacy in early grades affects their mastery of other aspects of the curriculum. Studies by Mtitu (2014) and Gurney (2007) identified teacher preparedness as a crucial dimension that could help improve learner's performance in Mathematics. According to Gurney (2007), teaching is effective when teachers deliver the right content and have enough learning materials on the teaching activity. Mtitu (2014) identified that learner centered methods require teachers to actively involve students in the teaching and learning process. This requires a teacher to have passion in sharing knowledge with students while armed with appropriate tools and competencies in content delivery. Rowan and Ball (2005) state that teacher training is an important prerequisite in preparation for teaching; it involves activities such as collection of materials required for the lesson, lesson planning and assessment during the lesson, adding that teacher preparation is central to the work of teaching and functioning of an education system. Hill, Rowan and Ball (2000) argue that teacher preparedness to teaching have been identified as amongst the most critical factors that contribute to teacher's work performance, absenteeism, burnout, and turnover in addition to having a significant influence on learners academic achievement. Therefore teachers who prepare adequately for Mathematics lessons are able to effectively deliver the Mathematics concepts to learners effectively and in a style that promotes understanding and internalization of the taught content. In agreement to this view Wilson, Floden and Ferrini-Mundy (2012) notes that teachers' professional preparedness also encompasses the relationship that teachers have established with the learners. If the teacher has strained connection with learners, then the lesson delivery will be poor due to the emotional distance between the teacher and learners. According to Wilson, Floden and Ferrini-Mundy (2012) teacher preparedness is even more broader and encompasses the quality of their relationships with learners, fellow teachers and other school employees, specifically, the extent to which they enjoy mutual support in managing classroom instruction and interpersonal relationships in the workplace. Consequently, teachers' preparation for teaching would require assistance from colleagues and all other stakeholders in education. Therefore when there is strained relationship in the school, the teachers' lesson preparation may be hindered.

Bass and Ball (2000) state that research on teaching in Mathematics suggests that many teachers do not possess the prerequisite content to implement high-quality instruction. The logic underlying Bass and Ball (2000) and Kilpatrick, Swafford and Findell (2001) was that teachers who possess strong mathematical knowledge at a greater depth and span are more likely to foster students' ability to reason, conjecture and problem-solving. They are able to more accurately diagnose and address students' mathematical (mis)conceptions and computational (dys) fluencies. Kilpatrick, Swafford and Findell (2001) argued that teachers must deepen their knowledge of the content, including proper sequencing and closure of the topics as well as the topics that precede and follow them. Rivkin, Hanushek and Kain (2005) was of the view that central to raising student achievement in Mathematics is improving the quality of Mathematics teaching. Students who receive high-quality instruction experience greater and more persistent achievement gains than their peers who receive lower-quality instruction. They hold that students who were taught by highly effective teachers achieved a gain of 1.5 grade equivalents during a single academic year, whereas students enrolled in classes taught by ineffective teachers gained only 0.5 grade equivalents in the same year. Moreover, the effects of high-quality instruction on the academic achievement of disadvantaged students are substantial enough to counteract the host of familial and social conditions often found to impede student achievement (Rivkin, Hanushek \& Kain, 2005). To put it differently, teachers are critical determinants of student learning and educational progress and thus must be well trained to use effective teaching practices. The literature discussed clearly shows that teachers' preparation affects the performance of learners in Mathematics subject and other subjects.

Hill, Ball and Schilling (2008) posited that knowledge about content delivery methods in Mathematics differs in important ways from content knowledge possessed by the professional in the same discipline. Ball, Lubienski and Mewborn (2001) report that mathematics teachers must be proficient in not only the content, but also how to deliver the same to the students. Moreover, teachers must understand how students reason and employ strategies for solving mathematical problems and how students apply or generalize problem-solving methods to various mathematical contexts. The use of language, construction of metaphors and scenarios appropriate to teaching mathematical concepts and understanding of the use of instructional resources in the practice of teaching. 
Competency in the content coupled with the proper application of pedagogical skills constitute a knowledge base for effective teaching of mathematics. These understandings represent the specialized content knowledge and preparedness. Isiugo-Abanihe, Ifeoma and Tandi (2010) emphasized that the responsibility of checking the professional documents like teachers' schemes of work and lesson plans lies in the hands of the head teacher. Preparation and use of schemes of work by the teachers enhance sequential teaching and results to improved achievement. Isiugo-Abanihe, Ifeoma and Tandi (2010) indicated that the head teachers randomly checked the teachers' schemes of work only once a term. They argued that lack of regular and close monitoring could be a factor contributing to poor performance in national examinations particularly in Mathematics. The studies have shown that there is a general consensus that teacher professional preparation contributes to academic performance of their learners. It is therefore necessary that the school administration and the teachers ensure that they prepare in advance for teaching and learning to be effective. Studies demonstrate that teacher preparation plays an important role in ensuring that learners attain better learning outcomes in education. Researches reviewed attest to the fact that better prepared teachers tend to post good grades in national examinations.

\section{Statement of the Problem}

The influence of teacher preparedness on performance of learners especially in Mathematics in lower primary schools is not clearly documented. Attainment of knowledge in numeracy by learners in lower primary school lays an important foundation for future learning particularly in Mathematics and Sciences (Makewa, Role, Too \& Kiplagat, 2012). However, reports by the Kenya National Examinations Council (KNEC) reveal that pupils' performance in Mathematics continues to decline every year. Aberdares region in Kenya has continued to post poor performance in Mathematics among the lower primary school learners (SCEO, 2015). The sub-county education office has consistently indicated that pupils are not acquiring the desired levels of competence. However, although there may be several factors that hinder learning of Mathematics, there is limited literature on studies related to teacher preparedness which is a key factor to pupils' performance. This study sought to address this gap by evaluating the influence of teacher preparedness on learners' performance in mathematics.

\section{Purpose of the Study}

The purpose of this study was to evaluate the influence of teacher preparedness on performance of pupils in Mathematics performance in lower primary schools in Aberdares region, of Kenya.

\section{Objectives}

The study was guided by the following objectives, which were to;

i. Evaluate the influence of teachers' preparation of lesson plans on pupils' performance in Mathematics in lower primary schools from the Aberdares region in Kenya.

ii. Assess the influence of teachers' preparation of schemes of work on performance in Mathematics among pupils in lower primary schools in Aberdares region in Kenya.

\section{Hypotheses}

The study tested the following hypotheses;

Ho1: There is no statistically significant relationship between teachers' preparation of lesson plans and performance in Mathematics among pupils in lower primary schools.

Ho2: There is no statistically significant relationship between teachers' preparation of schemes of work and performance in Mathematics among pupils in lower primary schools.

\section{Theoretical Framework}

This study was guided by social constructivism theory (SCT) advanced by Vygotsky (1978). SCT holds that all cognitive functions originate in and must be explained as products of social interactions. The theory explains that learning is not simply the assimilation and accommodation of new knowledge by learners but a process by which learners are integrated into a knowledge community. The theory stresses that learning takes place within school environments where interaction of the learners, the learning environment and the teachers ensures that learning takes place. The theory is relevant to the study because it helped to holistically analyze the variables at play during the teaching and learning processes. Constructivism theory was instrumental in analyzing the meditational role of the teacher in integrating the subject matter, the learning environment and the learner through instructional preparedness in ensuring realization of the desired learning outcomes in the learning of Mathematics. 


\section{METHODOLOGY}

The study adopted the descriptive survey research design. This research design enabled evaluation of the variables by obtaining facts and opinions without their manipulation. This design was appropriate in relation to the variables in the study because it helped to describe the situation and report as it was without their manipulation. The target population for the study consisted of all the 385 teachers and 1320 pupils in the public primary schools in Aberdares region of Kenya.

A sample of schools was selected using the Gay 10-20\% sampling principle which yielded a sample size of 77 teachers and 264 pupils (see Table 1). Data was analyzed using both the descriptive and inferential statistics.

Table 1. Sample size

\begin{tabular}{lccc}
\hline Data Set & Population & Sample Size & Percentage \\
\hline Teachers & 385 & 77 & $20 \%$ \\
\hline Lower Primary Pupils & 1320 & 264 & $20 \%$ \\
\hline Totals & $\mathbf{1 7 6 0}$ & $\mathbf{3 5 2}$ & $\mathbf{4 0 \%}$ \\
\hline
\end{tabular}

\section{RESULTS AND DISCUSSION}

The results and discussion are presented in accordance with the stated objectives and hypotheses that guided the study. These were;

a) The first research objective sought to examine the influence of teachers' preparation of lesson plans on pupils performance in Mathematics in primary schools in Aberdares Region in Kenya. The study further tabulated the pupils mean scores in mathematics in relation to teachers' preparation of mathematics lessons plans. The results presented in Table 2 revealed that $23(29.9 \%)$ of the teachers did not prepare lesson plans compared to $54(70.1 \%$ ) who did. The findings further established that the overall mean scores of the learners' performance in Mathematics was 59.8 and a standard deviation of 6.8. This mean score indicates that students' had an average level of competence in Mathematics. The results further revealed that pupils whose teachers prepared lesson plans performed better $(\bar{x}=63.9)$ with a standard deviation of 6.31. Those teachers who did not prepare lesson plans had $(\bar{x}=57.3)$ and a standard deviation of 8.01. Results suggest that teachers' preparation of lesson plans was being reflected in higher scores in Mathematics among the pupils. The findings are consistent with Rowan and Ball (2005) which reported that teacher preparation of lessons is critical in the attainment of the appropriate competencies by learners. Rowan and Ball (2005) argue that teacher preparation and commitment to teaching have been identified as amongst the most critical factors in the success and future of education.

Table 2. Lesson plans and pupils' performance in Mathematics

\begin{tabular}{lccc}
\hline Prepared Lesson Plans & Frequency & $\begin{array}{c}\text { Mathematics } \\
\text { Mean }(\boldsymbol{x})\end{array}$ & Standard Deviation (s) \\
\hline Yes & $54(70.1 \%)$ & 63.9 & 6.31 \\
\hline No & $23(29.9 \%)$ & 57.3 & 8.01 \\
\hline Total & $\mathbf{7 7 ( 1 0 0 \% )}$ & $\mathbf{5 9 . 8}$ & $\mathbf{6 . 8 3}$ \\
\hline
\end{tabular}

It was hypothesized that there was no statistically significant relationship between teachers' preparation of lesson plans and pupils' performance in Mathematics in lower primary schools in Aberdares region in Kenya. To test the hypothesis, t-test statistic was computed. The computed t-test yielded a p-value $=0.027$ which was less than the $\alpha$-value of 0.05 (see Table 3 ). The null hypothesis was rejected and it was concluded that there was statistically significant differences in pupils mean scores among pupils in schools where teachers prepared lesson plans compared to schools where teachers did not. Teachers' preparation of lesson plans had a positive impact on pupils' acquisition of Mathematical competence. The study agreed with the findings of Armstrong, Henson and Savage (2009) who opined that teachers who planned their lessons with consideration of learners' mental abilities in mind were likely to foster learning. Armstrong, et al. (2009) argued that while teaching, the teacher should treat the content to be taught by first identifying the desired results from learning of the content. ; Secondly, break the content into smaller components or sub- tasks that logically build towards the desired results and finally, adopt appropriate teaching approaches for each of the components together with specifying the lesson objectives in relation to the grades where the learning will take place. Hence, the teaching and learning process involves meticulous treatment and preparations to ensure attainment of desired learning outcomes by the learner. 
European Journal of STEM Education, 2019, 4(1), 01

Table 3. Results of t-test on teachers' preparation of lesson plans and pupils mean scores in Mathematics

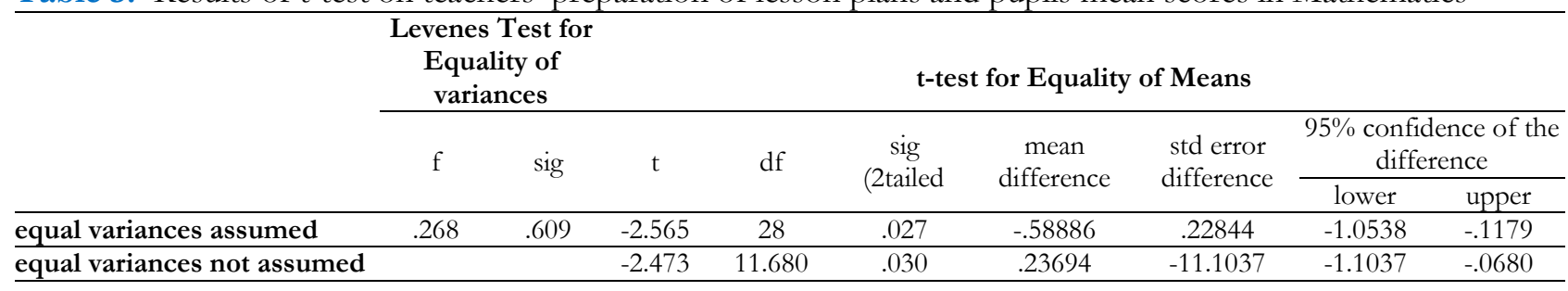

b) The second objective evaluated the influence of teacher of preparation of schemes of work on pupils' performance in Mathematics in lower primary schools in Aberdares Region in Kenya. The study tested the hypothesis that there was no statistically significant relationship between teachers' preparation of lesson plans and pupils' performance in Mathematics in lower primary schools. The findings presented in Table 4 indicate that the p-value of .039 was less than the $-\alpha=.05$. Therefore we accept the null hypothesis. The conclusion was that there was statistically significant difference in the mean scores. The performance in Mathematics was relatively similar regardless of whether the teacher prepared schemes of work or not.

The results were divergent with the findings of Kilpatrick, Swafford and Findel (2001) who had argued that teacher's preparation was statistically related to learner's academic performance in Mathematics. The findings in this current study could be attributed to teachers experience in teaching Mathematics. Demographic data showed that majority of the teachers who were over $80 \%$ had over 5 years of teaching Mathematics. This shows that teacher experience has an influence in the attainment of learners' competencies in a particular subject. However, more research is required in order to conclusively make an authoritative verdict.

Table 4. Results of t-test on teachers preparation of schemes of work and pupils' performance in Mathematics

\begin{tabular}{|c|c|c|c|c|c|c|c|c|c|}
\hline & \multicolumn{2}{|c|}{$\begin{array}{c}\text { Levenes Test for } \\
\text { Equality of variances }\end{array}$} & \multicolumn{7}{|c|}{ t-test for Equality of Means } \\
\hline & \multirow[t]{2}{*}{$\mathrm{f}$} & \multirow[t]{2}{*}{ sig } & \multirow[t]{2}{*}{$\mathrm{t}$} & \multirow[t]{2}{*}{ df } & \multirow{2}{*}{$\begin{array}{l}\text { sig } \\
\text { (2tailed }\end{array}$} & \multirow{2}{*}{$\begin{array}{c}\text { mean } \\
\text { difference }\end{array}$} & \multirow{2}{*}{$\begin{array}{l}\text { std error } \\
\text { difference }\end{array}$} & \multicolumn{2}{|c|}{$\begin{array}{c}95 \% \text { confidence of the } \\
\text { difference }\end{array}$} \\
\hline & & & & & & & & lower & upper \\
\hline ual ve & 6.056 & .039 & .972 & 8 & .35 & 4.000 & 4 & -5.486 & 13.486 \\
\hline qual variances not assume & & & .972 & 4.023 & .386 & 4.000 & 4.113 & -7.389 & 15.389 \\
\hline
\end{tabular}

\section{CONCLUSION}

The findings of the study indicate that teacher preparedness as indicated by preparation of lesson plans had an influence on pupils' performance in Mathematics in lower primary school. Preparation of schemes of work had no influence on performance. There were statistically significant differences between pupils mean scores for schools where teachers prepared lesson plans and those who didn't. However, the study established that there was no statistically significant difference in the pupils' performance in relation to teachers' preparation of schemes of work.

\section{RECOMMENDATIONS}

Arising from the findings of this study, we recommend the need for teachers in lower primary schools to always prepare for their lessons before commencement of teaching. The Ministry of Education should always emphasize that teachers must prepare prerequisite professional documents that are instrumental in enhancing learning outcomes among learners especially that of Mathematics in the lower primary segment of education. Teachers who fail to comply with this requirement should be severely censured. 


\section{REFERENCES}

Akatekit, D. D. (2000). An evaluation of teachers' methods in P310/3 (Novels). Dissertation submitted for the degree of Master of Education at Makerere University. Kampala

Armstrong, D. G., Henson, K. T. and Savage, T. V. (2009). Teaching today: An introduction to education (8 $8^{\text {th }}$ ed.). Upper Saddle River, New Jersey, OH: Pearson.

Ball, D. L. and Bass, H. (2000). Interweaving content and pedagogy in teaching and learning to teach: Knowing and using mathematics. In J. Boaler (Ed.), Multiple perspectives on the teaching and learning of mathematics (pp. 83104). Westport, CT: Ablex.

Gay, L. R. (2006). Educational Research: Competencies for analysis and application (5 $5^{\text {th }}$ ed.). Englewood Cliffs, NJ: PrenticeHall.

Gurney, P. (2007). Five Factors for Effective Teaching. New Zealand Journal of Teachers' Work, 4(2), 89-98.

Hill, H. C., Ball, D. L. and Schilling, S. G. (2008). Unpacking pedagogical content knowledge: Conceptualizing and measuring teachers' topic-specific knowledge of students. Journal for Research in Mathematics Education, 39(4), 372 400.

Hill, H. C., Rowan, B. and Ball, D. L. (2005). Effects of teachers' mathematical knowledge for teaching on student achievement. American Educational Research Journal, 42(2), 371-406. https://doi.org/10.3102/00028312042002371

Isiugo-Abanihe, M., Ifeoma, L. and Tandi, I. (2010). Evaluation of the Methodology Aspect of Science Teacher Education Curriculum in Nigeria. Pakistan Journal of Social Sciences, 17(2), 170-176. Available at: http://www.medwelljournals.com/fulltext/?doi=pjSsci.2010.170.170

Kilpatrick, J., Swafford, J. and Findell, B. (Eds.). (2001). Adding it up: Helping children learn mathematics. Washington DC: National Academies Press.

Makewa, L. N., Role, E., Too, J. K. and Kiplagat, P. (2012). Teacher commitment and mathematics performance in primary schools: A meeting point!. International Journal of Development and Sustainability, 1(2), 286-304.

Mtitu, E. A. (2014). Learner-centred teaching in Tanzania: Geography teachers' perceptions and experiences. Victoria University of Wellington.

Oketch, M., Mutisya, M., Ngware, M. and Sagwe, J. (2010). Teacher math test scores: Classroom teaching practices and student achievement in Kenya. Working paper, African Population and Health Research Center (APHRC), Shelter Afrique Center, Nairobi.

Rivkin, S, G., Hanushek, E. A. and Kain, J. F. (2005). Teachers, schools, and academic achievement. Econometrica, 73(2), 417-458. https:// doi.org/10.1111/j.1468-0262.2005.00584.x

Uwezo (2016). Are Our Children Learning? Uwezo Kenya Sixth Learning Assessment Report. Nairobi: Twaweza East Africa.

Vygotsky, L. S. (1978). Mind in Society: The Development of Higher Psychological Processes. Cambridge, MA: Howard University Press.

Wilson, S. M., Floden, R. E. and Ferrini-Mundy, J. (2012). Teacher preparation research: An insider's view from the outside. Journal of Teacher Education, 53(3), 190-204. https://doi.org/10.1177/0022487102053003002 